\title{
Changes in fermentation processes as the effect of vegetable oil supplementation in in vitro studies
}

\author{
M. Szumacher-Strabel ${ }^{1,4}$, S.A. Martin ${ }^{2}$, A. Potkański ${ }^{1}$, A. Cieślak ${ }^{1}$ \\ and J. Kowalczyk ${ }^{3}$
}

\author{
${ }^{1}$ August Cieszkowski Agricultural University, \\ Department of Animal Nutrition and Feed Management \\ Wotyńska 33, 60-637 Poznań, Poland \\ ${ }^{2}$ The University of Georgia, Department of Animal and Dairy Science \\ Athens 30602-2771, USA \\ ${ }^{3}$ The Kielanowski Institute of Animal Physiology and Nutrition, \\ Polish Academy of Sciences \\ 05-110 Jabtonna, Poland
}

\begin{abstract}
The effect of 5\% rapeseed, sunflower or linseed oil supplementation to a high-concentrate diet on basic rumen parameters, methane emission, rumen bacteria and protozoa counts was estimated in vitro in batch culture studies. The inclusion oils differing in fatty acid composition did not affect the $\mathrm{pH}$ or ammonia level of rumen contents but decreased VFA and butyric acid levels $(\mathrm{P} \leq 0.05)$, whereas the level of particular VFAs and the acetate-to-propionate ratio were not influenced by different oils. Protozoa number was significantly decreased by all supplemented oils, whereas no effect of fat on bacteria count was noted. As the number of unsaturated bonds in the supplemented oils increased, the protozoa counts decreased. Each oil only slightly decreased in vitro dry matter disappearance $(\mathrm{P}>0.05)$. Methane emission was reduced $(\mathrm{P} \leq 0.01)$ when oils were added to the incubates.
\end{abstract}

KEY WORDS: rumen parameters, methane, bacteria, protozoa, vegetable oils, rumen

\section{INTRODUCTION}

Fat supplementation to ruminant diets can result in abnormal rumen fermentation, including a decreased level of volatile fatty acids and ammonia. The effect of added fat seems to be dependent on its fatty acid composition. According to McAllister et al. (1996) C18 polyunsaturated fatty acids are usually

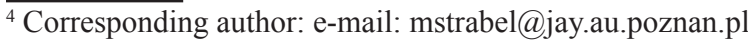


characterized as the most toxic to rumen microflora and have a negative impact on ruminal processes.

There is relatively little information available detailing the effect of fat supplemented to high-concentrate diets, usually fed to young growing animals, on rumen metabolites and methane emission, therefore the objective of this study was to examine the effects of three vegetable commercial oils supplemented to a highconcentrate diet on methane emission, basic rumen metabolites and number of microorganisms grown in a batch culture system.

\section{MATERIAL AND METHODS}

Rumen fluid was collected $2 \mathrm{~h}$ after feeding from Polish Merino ewes maintained on standard concentrate-hay. Rumen fluid was diluted with buffer (2:3) solution (292 mg K $\mathrm{HPO}_{4}, 240 \mathrm{mg} \mathrm{KH} \mathrm{PO}_{4}, 480 \mathrm{mg}\left(\mathrm{NH}_{4}\right)_{2} \mathrm{SO}_{4}, 480 \mathrm{mg} \mathrm{NaCl}$, $100 \mathrm{mg} \mathrm{MgSO}{ }_{4} 7 \mathrm{H}_{2} \mathrm{O}, 64 \mathrm{mg} \mathrm{CaCl} 22 \mathrm{H}_{2} \mathrm{O}, 4 \mathrm{mg} \mathrm{Na} \mathrm{CO}_{3}$ and $600 \mathrm{mg}$ cysteine hydrochloride per liter) and $40 \mathrm{ml}$ transferred to incubation vessels containing $0.4 \mathrm{~g}$ substrate and incubated in anaerobic conditions at $\mathrm{pH} 6.5$ and $39^{\circ} \mathrm{C}$ in duplicate samples. The substrate was composed of, g: hay 0.156 , wheat 0.125 , barley 0.078 , rapeseed meal 0.031 , mineral mixture 0.09 for control group but supplemented with $0.019 \mathrm{~g}$ rapeseed (source of C18:1), sunflower (source of C18:2) or linseed (source of C18:3) oil.

After $24 \mathrm{~h}$ incubation, samples of gas to measure methane content (GC, Hewlett Packard) and liquid were taken for analysis of $\mathrm{pH}$ and bacteria; protozoa classified into Entodiniomorphs and Holotrichs were counted. The remaining fluid was centrifuged $\left(10000 \times \mathrm{g}, 4^{\circ} \mathrm{C}, 15 \mathrm{~min}\right)$ and the cell-free supernatant was stored at $-20^{\circ} \mathrm{C}$ until analysis for VFA (GC, Varian, Star $3400 \mathrm{CX}$ ) according to Tangerman and Negengast (1996), and ammonia spectrometrically (Nessler method, absorbance $400 \mathrm{~nm}$ ). In vitro dry matter disappearance (IVDMD) was calculated from the difference of the original dry sample and dry residue weights.

All data were analysed using SAS procedures (User Guide, 1990)

\section{RESULTS}

The inclusion of $5 \%$ of vegetable oils differing in fatty acid concentrations (Table 1) did not affect the rumen fluid $\mathrm{pH}$ or ammonia level. Each of the fat supplements reduced $(\mathrm{P} \leq 0.05)$ the level of volatile fatty acids from $102.1 \mathrm{mmol} / \mathrm{L}$ in the control group to $91.5,81.4$ and $78.9 \mathrm{mmol} / \mathrm{L}$ in incubates with rapeseed, sunflower or linseed, respectively. Linseed oil, rich in linolenic acid, was found to have the highest detrimental effect on VFA level. All vegetable oils decreased $(\mathrm{P} \leq 0.05)$ the level of butyric acid and, similarly as in the case of VFAs, the highest effect was obtained when linseed oil was added. Oils did not influenceparticular VFAs or the 
acetate-to-propionate ratio, but the butyrate level was significantly depressed in incubates containing oils.

Table 1. Effect of vegetable oils on $24 \mathrm{~h}$ in vitro fermentation pattern of high-concentrate diets studied in batch culture (mean values)

\begin{tabular}{|c|c|c|c|c|}
\hline \multirow{3}{*}{ Item } & \multicolumn{4}{|c|}{ Treatment } \\
\hline & control & rapeseed oil & sunflower oil & linseed oil \\
\hline & \multicolumn{4}{|c|}{$\mathrm{n}$} \\
\hline \multicolumn{5}{|l|}{ Rumen fluid properties } \\
\hline $\mathrm{pH}$ & 7.0 & 6.6 & 6.3 & 6.4 \\
\hline ammonia, mmol/L & 13.6 & 14.5 & 13.0 & 12.5 \\
\hline volatile fatty acids, $\mathrm{mmol} / \mathrm{L}$ & 102. $1^{\mathrm{AA}}$ & $91.5^{\mathrm{AB}}$ & $81.4^{\mathrm{BB}}$ & $78.9^{\mathrm{BB}}$ \\
\hline acetate $(\mathrm{A})$ & 56.9 & 52.8 & 45.9 & 45.7 \\
\hline propionate $(\mathrm{P})$ & 25.4 & 22.5 & 20.4 & 19.4 \\
\hline butyrate & $12.8^{\mathrm{AA}}$ & $10.7^{\mathrm{AB}}$ & $10.3^{\mathrm{AB}}$ & $9.1^{\mathrm{BB}}$ \\
\hline $\mathrm{A} / \mathrm{P}$ & 2.2 & 2.3 & 2.2 & 2.3 \\
\hline \multicolumn{5}{|l|}{ Rumen fluid microbial counts } \\
\hline bacteria, $10^{8} \mathrm{ml}^{-1}$ & 14.4 & 13.6 & 14.0 & 11.7 \\
\hline protozoa, $10^{3} \mathrm{ml}^{-1}$ & $9.3^{\mathrm{AA}}$ & $7.5^{\mathrm{AB}}$ & $6.4^{\mathrm{BB}}$ & $6.0^{\mathrm{BB}}$ \\
\hline IVDMD $^{1}, \%$ & 42.3 & 41.6 & 41.7 & 38.0 \\
\hline methane, $\mathrm{mM}$ & $7.4^{\mathrm{aa}}$ & $5.4^{\mathrm{bb}}$ & $4.8^{\mathrm{bb}}$ & $3.7^{\mathrm{cc}}$ \\
\hline
\end{tabular}

means with the same letter are not significantly different, ${ }^{\mathrm{A}, \mathrm{B}}-\mathrm{P}<0.05 ;{ }^{\text {a }}{ }^{\mathrm{b}, \mathrm{c}}-\mathrm{P}<0.01$

${ }^{1}$ in vitro dry matter disappearance

The number of protozoa significantly decreased as the number of unsaturated bonds in the supplemented oils increased, but the bacteria count was not depressed by oils.

IVDMD decreased slightly but not significantly in incubates supplemented with oils. Nevertheless, the type of oil supplemented reduced $(\mathrm{P}<0.01)$ methane emission, as production of methane decreased from $7.48 \mathrm{mM}$ in the control incubate to 5.4, 4.8 and $3.7 \mathrm{mM}$ in incubates with rapeseed, sunflower or linseed oils, respectively.

\section{DISCUSSION}

In the presented experiments, when the substrate in the rumen liquid was mostly concentrate, a detrimental effect of supplementing 5\% fat as a vegetable oil on rumen processes was not demonstrated. Oils did not alter $\mathrm{pH}$ or ammonia levels, bacteria counts were similar in all groups. A high concentrate diet with different supplemented oils did not change the IVDMD. Only slight but significant decreases in the total VFAs, butyrate level, and protozoa count were observed. Similar results were reported by Dong et al. (1997) who did not find a direct effect of rapeseed oil in concentrate diets on $\mathrm{pH}$ and ammonia levels in vitro, but fat addition decreased the VFA level in 
rumen fluid. However, incorporation of sunflower oil in vitro in experiments carried out by Ivan et al. (2001) decreased acetate-propionate ratio in oil-supplemented rumen liquid in comparison with controls. A stronger effect of fat on feed digestibility and carbohydrateand nitrogen metabolic pattern could probably be achieved at a higher level of fat supplementation, as was demonstrated in experiments in vivo on sheep by Kowalczyk et al. (1977), Jenkins (1993) and Doreau and Chilliard (1997). In summarizing factors affecting the level and proportion of fatty acids in rumen fluid Hvelplund (1991) included the type of diet fed and fat supplements.

As an indirect effect of limited protozoa counts, we observed the suppressing effect of unsaturated fatty acids from oils on methane emission. According to Machmüller et al. (1998) the reason for the methane-suppressing effects of fats either rich in saturated fatty acids or unsaturated ones was a direct effect against the rumen microbes involved in methane production.

\section{CONCLUSIONS}

Applied up to $5 \%$ in a diet composed mostly of concentrate, vegetable oils differing in fatty acid composition did not have a detrimental effect on the rumen fermentation pattern. However, oils can decrease the butyrate level and protozoa counts in the rumen liquid resulting in a decrease of methane emission.

\section{REFERENCES}

Dong Y., Bea H.D., McAllister T.A., Mathison G.W., Cheng K.G., 1997. Lipid induced depression of methane production and digestibility in the artificial rumen system (RUSITEC). Can. J. Anim. Sci. 77, 269-278

Doreau M., Chilliard Y., 1997. Digestion and metabolism of dietary fat in farm animals. Brit. J. Nutr. 78, Suppl. 1, 15-35

Hvelplund T., 1991. Volatile fatty acids and protein production in the rumen. In: J.P. Jouany (Editor). Rumen Microbial Metabolism and Ruminant Digestion. INRA Edition, Paris, pp. 165-178

Ivan M., Mir P.S., Koenig K.M., Rode L.M., Neill L., Entz T., Mir Z., 2001. Effects of sunflower seed oil on rumen protozoa population and tissue concentration of conjugated linoleic acid in sheep. Small. Ruminant Res. 41, 215-227

Jenkins T., 1993. Lipid metabolism in the rumen. J. Dairy Sci. 76, 3851-3863

Kowalczyk J., Ørskov R.R., Robinson J.J., Steward C.S., 1977. Effect of fat supplementation on voluntary feed intake and rumen metabolism in sheep. Brit. J. Nutr. 32, 251-257

Machmüller A., Ossowski D.A., Wanner M., Kreuzer M., 1998. Potential of various fatty feeds to reduce methane release from rumen fermentation in vitro (Rusitec). Anim. Feed Sci. Tech. 71, $117-130$

McAllister T.A., Okine E.K., Mathison G.W., Cheng K.J., 1996. Dietary, environmental and microbiological aspects of methane production in ruminants. Can. J. Anim. Sci. 76, 231-243

User Guide, 1990. SAS ${ }^{\circledR}$, SAS/STAT (Release 6.03). SAS Institute Inc., Cary, NC

Tangerman A., Negengast F.M., 1996. A gas chromatographic analysis of fecal short-chain fatty acids using the direct injection method. Anal. Biochem. 236, 1-8 